\title{
Applying Behavioral Science in Combating COVID-19 at the Workplace: A Narrative Review
}

Dzifa Francis Ahadzi*

Center for Occupational Safety and Health

Health and Safety Group Africa (HESAG Africa)

Cape Coast, Ghana

Email: dzifa.hesag@gmail.com

Hattie-Mary Owusu

Center for Occupational Safety and Health

Health and Safety Group Africa (HESAG Africa)

Cape Coast, Ghana

Email: hattie.hmo@gmail.com

John Ekow Otoo

Bono Regional Health Directorate

Ghana Health Service

Sunyani, Ghana

Email: johnotoo.05@gmail.com

Emily Esenam Akumah

Nimzi Ltd

Accra, Ghana

essynam@gmail.com

*Author to whom correspondence should be addressed

Declaration of interest: None

\begin{abstract}
Practicing preventive etiquettes such as hand washing, hand disinfection, wearing a face mask, practicing physical distancing, disinfection of surfaces and objects can help curb the transmission of COVID-19 at the workplace. This paper focuses on interventions and behaviors required to curb the spread of COVID-19 at workplaces. We undertook a detailed multi-disciplinary literature search on the following topics: hand hygiene, respiratory hygiene, physical distancing, quarantine and isolation, disinfection of objects and surfaces, behavior change, and health crisis communication. We identified interventions that are effective for preventing the spread of severe acute respiratory syndrome coronavirus 2 (SARS-Cov-2) at workplaces. These findings present very useful non-clinical interventions for preventing COVID-19 in the work environment.
\end{abstract}

Keywords: COVID-19, behavioral interventions, prevention, workplace safety, safety protocols 


\section{Introduction}

The world of work has changed since the outbreak of the COVID-19 pandemic. Severe acute respiratory syndrome coronavirus 2 (SARS-Cov-2) poses a health and safety concern for the global workforce and workplaces. While respiratory infections are not new, they are by no means a worry of the past (Sim et al., 2014). Healthcare workers per the nature of their work seem to be at a higher risk of contracting COVID-19, however, a recent study has revealed that other workers in the tourism, hospitality, transport, security, and construction industries are equally highly exposed to the virus (Koh, 2020). Since the outbreak of the pandemic, substantial attention has been focused on workplace infection prevention etiquette. The current situation has triggered a rapid behavioral change within work settings. Promoting and observing the COVID-19 safety protocols at workplaces is critical to protecting the safety and health of employees and management. Behavioral interventions are being adopted globally to suppress the transmission of the virus in communities and workplaces (Bavel et al., 2020; Lunn et al., 2020; West et al., 2020).

Social and behavioral sciences provide relevant insights for managing COVID-19 (Bavel et al., 2020). Sawyer and White (2015) posited that behavioral changes such as not touching the face particularly the mouth, nose, or eyes can protect us from contracting the COVID-19 disease. Safety protocols such as handwashing or hand disinfection (Hogg \& Huston, 2006; Kratzel et al., 2020; Mbakaya et al., 2017; Pittet et al., 2000), wearing of face mask (Aiello et al., 2010; Feng et al., 2020; Killingley et al., 2011), physical distancing (Brzezinski et al., 2020; Cirrincione et al., 2020; C. I. Jarvis et al., 2020; Prem et al., 2020; Tuite et al., 2020), quarantine and isolation (Briscese et al., 2020; Cava et al., 2005; Esquivel-Gómez \& Barajas-Ramírez, 2018), and disinfecting objects and surfaces (Belingheri et al., 2020; Dexter et al., 2020; Fathizadeh et al., 2020; Kampf et al., 2020) can stop the spread of the virus at the workplace. Anderson et al., (2020) emphasized that adherence to the SARS-Cov-2 safety protocols can decrease the rate of transmission tremendously. Infection prevention practices are very essential in maintaining a safe and healthy workplace.

In this paper, we discussed topics that are relevant to the pandemic response at workplaces. The purpose is to inform policymakers, employers, managers, employees, and researchers to better understand how behavioral interventions can be used to curb the transmission of COVID-19 at the workplace. We address the following topics: hand hygiene, respiratory hygiene, physical distancing, quarantine and isolation, disinfection of objects and surfaces, behavior change, and health crisis communication. For each topic discussed, we highlight the relevant findings, important behavioral interventions that can be applied as a response to the COVID-19 in the workplace, and critical gaps for future research as the virus continues to spread at workplaces across the world. As a contribution to behavioral science knowledge, we suggested relevant behavioral interventions and guidelines for curbing the spread of COVID-19 at the workplace (Table 1).

\section{Hand Hygiene}

Hand hygiene has become an important intervention for fighting the COVID-19 since the outbreak of the global pandemic. It is one of the effective ways pathogens and infections can be prevented from spreading at the workplace. In the healthcare sector, hand hygiene is widely accepted as a basic clinical practice for preventing infections among workers and patients (Elaine Larson, 1988). Universally, one of the interventions that have been embraced as an effective infection control measure is hand hygiene. Frequent handwashing is an effective and inexpensive method of preventing the transfer of viral infections (Boyce \& Pittet, 2002; Curtis et al., 2009; Hogg \& 
Huston, 2006; Jefferson et al., 2009; Luby et al., 2005; Mbakaya et al., 2017; Voss \& Widmer, 1997). Information on when, why, and how workers should practice hand hygiene has been well documented (O’Boyle et al., 2001). However, it is well known that most workers do not wash their hands regularly at the workplace. Failure to wash the hands with soap contributes to almost $50 \%$ of disease outbreaks, meanwhile washing the hands with soap has the potential of decreasing the risk of infection by more than $40 \%$ (Borchgrevink et al., 2013). Washing the hand with soap under running water for a minimum of 20 seconds effectively cleans the hand (Table 1). Health experts have advised that in the absence of a paper tissue, we can cough or sneeze in a bent elbow instead of into the palm to prevent contamination of the hands.

Laboratory data has revealed that alcohol-based hand sanitizer or rub inactivates SARS-Cov-2 (Hogg \& Huston, 2006; Kratzel et al., 2020; Luby et al., 2005; Siddharta et al., 2017). Regarding healthcare settings, it is recommended that the hand sanitizer or rub contains at least $70 \%$ isopropanol (CDC, 2020). Alcohol-based hand sanitizers are handy, easy to use, and readily available (Ryan et al., 2001; White et al., 2003).

It has been widely reported that poor compliance with hand hygiene is common among workers particularly healthcare workers (Jarvis, 1994; Pittet et al., 2000; Voss \& Widmer, 1997). Reasons, why some workers do not comply with hand hygiene protocols, include forgetfulness, negligence, being too busy, skin irritation, wearing gloves, inaccessible handwashing supplies (Boyce \& Pittet, 2002; E. Larson \& Kretzer, 1995; Pittet, 2000). Understanding the importance of hand hygiene can significantly influence workers' adherence to hand hygiene protocols. Education and training are powerful strategies that can be utilized to promote hand hygiene compliance at the workplace. Research conducted by Pittet et al., (2000), revealed that workers' hand hygiene etiquette improved when they received education on it. However, using education and training to promote hand hygiene has not been without challenges. Edwards et al., (2012), posited that even in the working environment, efforts to enhance infection mitigation behaviors through education and awareness had short-period influences instead of long term improvements. However, evidence from existing literature suggests that some interventions improve hand hygiene among workers. These include access to hand hygiene facilities, the use of posters, and education to improve hand hygiene (Kretzer \& Larson, 1998; Naikoba \& Hayward, 2001; Pittet, 2000; Teare et al., 1999). Other studies have found that placing alcohol-based hand sanitizers or dispensers at more visible, proximate, and convenient locations increased usage significantly (Cure \& Van Enk, 2015; Gould et al., 2018; Hobbs et al., 2016).

When people react automatically to an object or person, that behavior is habitual and is often expressed in similar situations. Hand washing and disinfection, when done daily and regularly by workers becomes habitual (Aunger et al., 2010). Thus, the habit continues even when the motivation or interest disappears.

\section{Respiratory Hygiene}

In the work environment, respiratory etiquette requires that workers do not touch their face with unclean or contaminated hands. This requirement is necessary because there is the possibility of a contaminated hand introducing aerosolized droplets to the mucous membranes of the eyes, nose, and mouth (T-zone) and this could cause an infection. Studies have revealed that the T-zone is the only portal through which all respiratory infections enter the body (Bertsch, 2010; Goldmann, 2000; Lake, 2020; Sawyer \& White, 2015). SARS-Cov-2 (COVID-19). The mucous membranes of the eyes, nose, and mouth (T-zone) are the most touched areas of the face. Not touching your 
T-zone at all is a behavior change that could prevent infection (Sawyer \& White, 2015; West et al., 2020). A lot of respiratory pathogens are introduced to the eyes, nose, and mouth from the hand (Elder et al., 2014). For many people, touching the face is a habitual behavior that happens without thought and as such goes unnoticed (Nicas \& Best, 2008; Sawyer \& White, 2015). The prevalent behavior of touching the mouth, nose, and squeezing of the eyes is a latent act. The risk of getting a respiratory infection by touching the face with the hands depends on the rate of contact with the facial regions (Nicas \& Best, 2008). Research has found that people touch their T-zone 10-20 times per hour (Kwok et al., 2015). It has been reported that office workers touch their faces 16 times in an hour, also one in three healthcare workers pick their nose and rub their eyes while working (Elder et al., 2014; Nicas \& Best, 2008). Evidence shows that respiratory infections are minimized when the face is rarely touched (Elder et al., 2014).

The use of facemasks has become widespread since the emergence of the COVID-19. Using facemasks at the workplace has demonstrated to be an effective way of preventing aerosolized droplets from having contact with the T-zone. It also reduces the number of times the hand comes into contact with the T-zone. Sim (2014) found that people are more likely to put on their facemasks because of the fear of being infected with respiratory diseases. It has been well documented that facemasks are very useful in infectious disease control, particularly in preventing droplet transmission (Aiello et al., 2010; Chu et al., 2020; Eastwood et al., 2009; Furuya, 2007; Killingley et al., 2011). Facemasks effectively avert the forward movement of particles expelled from a cough or a sneeze (Sim et al., 2014). Ultimately, facemasks play a double role; it prevents aerosolized droplets from an asymptomatic or symptomatic person from getting to your T-zone and also stops the droplets from spreading when people sneeze or cough. Respiratory hygiene of workers is highly improved through the use of the facemask at the workplace (Table 1).

\section{Physical distancing}

The most effective way of preventing the spread of an infection is by breaking physical contacts (Chu et al., 2020; Drake et al., 2020; Huremović, 2019; C. I. Jarvis et al., 2020; Tuite et al., 2020). COVID-19 is spread through close contact between persons. To minimize the transmission of COVID-19 at the workplace, the global work community has introduced physical distancing guidelines. One of the most effective measures for reducing interpersonal transmission risk of COVID-19 at the workplace is physical distancing. Since the outbreak of COVID-19, many organizations across the globe have resorted to this safety measure to mitigate the spread of the virus in the work environment. The main objective of physical distancing is to stop the fast spread of SARS-Cov-2, allowing more time for public health experts and healthcare workers to study the disease and prepare adequately to treat it (Lewnard \& Lo, 2020; Prem et al., 2020). To promote physical distancing at the workplace, sitting arrangements have to be reorganized to ensure that workers sit at least, one meter apart (Table 1). Also, one-meter floor markings are necessary to indicate where managers, employees, clients, and visitors can stand to interact (Table 1). A study conducted by Islam et al., (2020), in 149 countries found that physical distancing observance reduced the prevalence of COVID-19 among the population. Kim (2020) found that the implementation of a physical distancing policy with specific guidelines is key to preventing the outbreak of COVID-19 at the workplace. Due to the occurrence of a significant number of group infections at workplaces, conditions for preventing COVID-19 infection at workplaces must include the physical distancing protocol (Kim, 2020). Physical distancing does not only minimize the cases but has the potential to minimize the severity of the cases (Dalton et al., 2020; Prem et al., 2020). Also, the frequency of contacts each person makes in the office or workplace is 
drastically reduced through the implementation of strict physical distancing protocols. Drake et al., (2020) argues that for these instructions and policies to be effective, compliance must be enforced.

\section{Quarantine and Isolation}

A potential spread of SARS-Cov-2 in the work environment poses a threat to workers' health and safety. Quarantine and Isolation have proven to be essential in preventing the transmission of COVID-19 (Wilder-Smith et al., 2020). Isolation and quarantine are interventions that can be applied to reduce COVID-19 transmission from one person to another. The outbreak of SARS in 2003 served as an example of a novel disease that was controlled effectively using quarantine and isolation (Day et al., 2006). Often, these two terminologies are used interchangeably (Rosenberger et al., 2012; Webb, 2015). Whereas isolation involves the separation of COVID-19 patients from healthy people, quarantine involves the restriction of movement of persons who have been potentially exposed to an infectious disease. Intensive quarantine is currently being undertaken around the world to help control the COVID-19 pandemic (Brooks et al., 2020). To stop the spread of COVID-19 at the workplace, measures must be put in place by management to identify and quarantine workers who had contact with people diagnosed with SARS-Cov-2 (Table 1). Workers who are quarantined must be observed for the occurrence of any symptoms of the virus. This can be done voluntarily or mandatorily by restricting affected persons to their home or at a designated facility. Similarly, steps must be taken to immediately isolate workers who have been confirmed to have COVID-19 to stop transmission to other workers who are healthy (Table 1). It has been established that isolating patients breaks the transmission of diseases (Rosenberger et al., 2012). The key to making these interventions effective is for management to consistently provide clear and adequate information on the disease, COVID-19, and the safety benefits of quarantine and isolation to workers.

\section{Disinfecting objects and surfaces}

Complying with hand hygiene, respiratory hygiene, quarantine, and isolation protocols alone cannot adequately stop the spread of COVID-19 at the workplace. Studies show that SARS-Cov2 can be spread at the workplace through contact with aerosol infested surfaces (Chan et al., 2020; Dowell et al., 2004; Fathizadeh et al., 2020; Otter et al., 2016; Whitworth, 2020). Since SARSCov-2 can remain on surfaces for several days, frequent disinfection of touched surfaces such as door handles, desks, chairs, computer keyboard and mouse, remote controls, and switches is needed to minimize the risk of contracting the virus at the workplace (Table 1). There is a long history of preventing infection by cleaning surfaces and objects with a disinfectant (Best \& Neuhauser, 2004). A study conducted by Kampf (2020) found that the virus can remain on surfaces such as plastic, metal, or glass for up to nine days, but can be effectively killed by disinfecting the surface with $62-71 \%$ ethanol, $0.5 \%$ hydrogen peroxide, or $0.1 \%$ sodium hypochlorite within one minute. It has been found that cleaning and disinfecting frequently touched surfaces is effective in killing the virus (Bialvaei et al., 2015). It is prudent that organizations promote non-clinical interventions such as disinfection and cleaning of frequently touched objects and surfaces to curb transmission in the work environment (Table 1). Transmission in the work setting can be successfully prevented when the right measures are strictly followed (Ki et al., 2019; Wiboonchutikul et al., 2016). 


\section{Behavior change}

To reduce COVID-19 transmission in the work environment, a rapid behavior change needs to be adopted and adapted by organizations to ignite a positive safety attitude among workers. In the absence of scientific evidence to inform policy and improve safety etiquette at the workplace, we can rely on the principles of behavior change to design strategies that can be effective during this pandemic. Behavior change is very probable to be achieved when the approach is made easy, timely, attractive, and social (The Behavioural Insights Team, 2020). Several relevant theories have been produced by behavioral scientists and these can easily be applied in managing the COVID-19 crisis in the work environment. A "behavior change wheel" model (Michie et al., 2011) has been proposed by West et al., (2020) as a behavior change strategy for minimizing the transmission of COVID-19. The "behavior change wheel" model proposed nine broad interventions that can be applied in any behavior change plan to achieve results: education, persuasion, incentivization, coercion, training, restriction, environmental restructuring, modeling, and enablement (Michie et al., 2011). This model can be easily used to design specific behavior change strategies to combat the COVID-19 at workplaces (Michie et al., 2013). For models like this to be effective, the work environment must promote behavior change, individuals must be prepared psychologically to follow safety instructions and interventions must be well explained for easy adoption and adaptation. Evidence shows that risk perception promotes behavioral responses (Sheeran et al., 2014). Underestimating risk may undermine efforts to change behavior (Lunn et al., 2020). People usually gravitate towards changing their risk perception downwards after a change in behavior (Brewer et al., 2004). West et al., (2020) posited that for people to accept personal protective behaviors, they need to understand what should be done, under what condition, how to do it, and why it is necessary to do it. The supply of personal protective equipment (PPE) and personal hygiene supplies is critical in ensuring that safety protocols are adhered to at the workplace. Helping the workforce in developing a positive safety attitude and sustaining it can significantly improve personal protective behavior at the workplace. Behavioral change can be achieved when workers and management become committed to fighting SARS-Cov-2 at the workplace.

\section{Health crisis communication}

Effective communication is critical to maintaining trust and confidence among workers during crises. The COVID-19 pandemic has plunged the global work community into a challenging health and safety situation. Organizations in the world have resorted to applying behavioral interventions as an effective strategy of curbing the spread of the disease in the work environment. For communication to be effective especially during pandemics, the message must be clear, unambiguous, and consistent. When information is unclear, it opens it up for people's interpretation and this can lead to ineffective application of the recommended guidelines (Braunack-Mayer et al., 2013). Apart from identifying effective messages for changing attitudes is the subject of how to instigate behavioral change (Bavel et al., 2020) especially when people are made to believe that their new attitude is the desired one (Luttrell et al., 2016). Behavioral change occurs when people begin to feel positive about their behavior (Rucker et al., 2014).

Applying the right communication strategies at the workplace in this COVID-19 times has the potential of preparing the minds of workers to be alert for uncertainties, adapt to new circumstances, and foster mutual trust with management. In crisis communication, it is important that organizations avoid fear-driven responses and instead constantly update the workforce about 
the measures being put in place to fight the health risk. Fear maximizes risk perception while anger minimizes it (Lerner \& Keltner, 2001). Blendon et al., (2008) argued that for communication to be impactful it must successfully inform, instruct, encourage the right self-protective behavior, keep up-to-date risk information, grow trust in officials, and get rid of all hearsays. Effective pandemic communication improves the capacity of the public to participate as competent stakeholders by advocating prevention, promoting containment, and encouraging resilience and recovery (Blendon et al., 2008; Holmes, 2008; Rasmussen et al., 2008). Satisfactory communication practices cannot replace poor planning and unenlightened policies (Vaughan \& Tinker, 2009). Very good communication approaches can become unproductive if management fails to involve employees at every level of planning, response, and recovery (Holmes, 2008; Maunder, 2004). The responsiveness of employees to the COVID-19 preventive measures will to some extent depend on management's ability to meet the communication needs of the employees. There is the tendency of workers losing trust in management when errors are made in communicating the right safety protocols, this is why accuracy must be applied at all times because errors can lead to undesirable outcomes.

Social media has unlocked contemporary channels for communication and engagement (Toppenberg-Pejcic et al., 2019) and presents opportunities for prompt information circulation (Kass-Hout \& Alhinnawi, 2013). Even though the evidence on the benefits of social media are inconsistent, it can be usefully explored by organizations to share information on COVID-19 among employees during a pandemic. Nonetheless, it has become increasingly clear that social media can lead to the dissemination of incorrect information (Bovet \& Makse, 2019). It has emerged that social media is generally ineffective for communicating official information during pandemics (Lunn et al., 2020). Individuals who depend on information from social media have a higher chance of experiencing fear and anger even though both responses are positively related to ensuing preventive behaviors (Oh et al., 2020). Inaccurate information and fake news about SARSCov-2 has been widely circulated on social media with its potentially negative repercussions (Frenkel et al., 2020). In these times of fake news, it is true that consistently sending messages across comes with its challenges but not meeting the information needs of the general public can be suicidal (Webster et al., 2020). In promoting the safety of workers, organizations must make it a duty to display posters of the safety protocols announced by the WHO at prominent places at their workplaces. Communication strategies are highly likely to become successful when they can be easily understood, when it is tailored from the viewpoint of the targeted group, and when the instructions are sensitive, integrated and fitting to the audience (Vaughan \& Tinker, 2009).

Evidences projected in this paper did not only focus on the current pandemic but were from varied pandemic situations and circumstances. Even though most of the evidence distilled are from healthcare settings, they are relevant and can be applied in other work settings. While the articles we relied on are not exhaustive, they provide a representative overview of literature on the topic. There is a dearth of published behavioral science articles on the current pandemic therefore there is the need to interpret the evaluation of the interventions highlighted in this paper with caution. In the table below are some relevant behavioral interventions and guidelines for curbing the spread of COVID-19 at the workplace (Table 1). 
Table 1: Behavioral interventions and guidelines required to curb the spread of COVID-19 at the workplace

\begin{tabular}{|c|c|c|}
\hline Safety protocol & Intervention & Management responsibility \\
\hline Hand hygiene & $\begin{array}{l}\text { Regular washing of hands under running water with } \\
\text { soap (for at least } 20 \text { seconds) or disinfection of hands } \\
\text { with alcohol-based hand rub containing at least } 60 \% \\
\text { alcohol. Avoid touching the T-Zone (eyes, nose, and } \\
\text { mouth) with your hands unless they have been washed } \\
\text { thoroughly or sanitized with an alcohol-based hand } \\
\text { rub. }\end{array}$ & $\begin{array}{l}\text { Provision of running water, soap, paper tissue, and } \\
\text { trash bins at vantage points at the workplace for staff, } \\
\text { clients, and visitors. Fixing of alcohol-based hand rub } \\
\text { dispensers at prominent places at the workplace. } \\
\text { Posters promoting handwashing and hand sanitizing } \\
\text { must be displayed at prominent places around the } \\
\text { workplace. }\end{array}$ \\
\hline $\begin{array}{l}\text { Respiratory } \\
\text { hygiene }\end{array}$ & $\begin{array}{l}\text { Compulsory wearing of face mask by all employees as } \\
\text { well as clients and visitors in the workplace. Use of } \\
\text { paper tissue to catch cough or sneeze at all times and } \\
\text { dropping the used tissue in a closed trash bin. }\end{array}$ & $\begin{array}{l}\text { Providing face masks for all employees. Ensuring } \\
\text { that no staff, client, or visitor enters the workplace } \\
\text { without wearing a face mask. Paper tissues must be } \\
\text { made available for catching cough and closed bins } \\
\text { provided for hygienically disposing of the tissues. } \\
\text { Posters on respiratory hygiene should be displayed at } \\
\text { key positions in the workplace. }\end{array}$ \\
\hline Physical distancing & $\begin{array}{l}\text { Re-organizing the sitting arrangements at the } \\
\text { workplace to ensure that workers sit at least } 1 \text { meter } \\
\text { apart to minimize physical contact. Introduction of } \\
\text { floor markings indicating where workers, clients, and } \\
\text { visitors can stand to interact. Introduction of a shift } \\
\text { system for workers to reduce the number of employees } \\
\text { that work in the same space. Reduction of the number } \\
\text { of participants at staff meetings and sometimes } \\
\text { conducting meetings and workshops virtually. }\end{array}$ & $\begin{array}{l}\text { Rearranging desks and marking the floor at the } \\
\text { workplace to introduce the recommended } 1 \text { meter } \\
\text { spacing between sitting positions and where people } \\
\text { can stand to interact. Instituting a shift system to } \\
\text { promote physical distancing. Posters promoting } \\
\text { physical distancing must be displayed around the } \\
\text { workplace. }\end{array}$ \\
\hline $\begin{array}{l}\text { Quarantine and } \\
\text { Isolation }\end{array}$ & $\begin{array}{l}\text { Separating and restricting workers who have been } \\
\text { exposed to people who have COVID-19 from their } \\
\text { healthy colleagues for } 14 \text { days. Isolating workers who } \\
\text { have contracted COVID-19 from those who are } \\
\text { healthy for prompt medical treatment. }\end{array}$ & $\begin{array}{l}\text { Management must conduct regular COVID-19 tests } \\
\text { on workers to ascertain individual statuses. Those } \\
\text { who test positive for the virus must be immediately } \\
\text { isolated and put on treatment. Those who had } \\
\text { contacts with COVID-19 patients must be }\end{array}$ \\
\hline
\end{tabular}




\begin{tabular}{|l|l|l|}
\hline & & $\begin{array}{l}\text { quarantined quickly. Posters indicating why } \\
\text { quarantine and isolation are important must be } \\
\text { displayed at vantage points at the workplace. } \\
\text { Facilities for quarantine and isolation must be } \\
\text { identified and prepared for the purpose. }\end{array}$ \\
\hline $\begin{array}{l}\text { Disinfecting } \\
\text { objects and } \\
\text { surfaces }\end{array}$ & $\begin{array}{l}\text { Regular disinfection and cleaning of objects and } \\
\text { surfaces that are frequently touched in the workplace } \\
\text { such as door handles, tables, chairs, computer } \\
\text { keyboard and mouse, stapler, remote controls, } \\
\text { switches, etc. must be carried out. }\end{array}$ & $\begin{array}{l}\text { Recommended disinfectants like } 60-70 \% \text { Ethanol or } \\
0.5 \% \text { Sodium Hypochlorite must be made available } \\
\text { for regular disinfection. Posters promoting regular } \\
\text { disinfection must be displayed at key places in the } \\
\text { workplace. }\end{array}$ \\
\hline
\end{tabular}




\section{Conclusion}

This paper discussed topics relevant to the COVID-19 pandemic response at workplaces. It provided evidences from research works on behavioral insights and interventions that can be applied to mitigate the impact of pandemics especially SARS-Cov-2. We particularly discussed the following relevant topics: hand hygiene, respiratory hygiene, physical distancing, quarantine/isolation, disinfection of objects and surfaces, behavior change, and health crisis communication. Evidences highlighted in this paper would help policymakers, employers, managers, and researchers to better appreciate how behavioral interventions can be utilized to curb the transmission of COVID-19 in workplaces. We suggested behavioral interventions and guidelines required to curb COVID-19 at the workplace in Table 1 as our contribution to knowledge on this important topic. Of all the interventions highlighted in this paper, effective health crisis communication stands tall as a critical intervention for producing desirable behavior. Ultimately, for all the above-mentioned behavioral interventions to work well, it would largely depend on the safety and health decisions of management and the safety attitude of workers. We believe the behavioral interventions projected in this article are important for reducing the spread of COVID-19 and other respiratory diseases in the work environment.

\section{References}

Aiello, A. E., Murray, G. F., Perez, V., Coulborn, R. M., Davis, B. M., Uddin, M., Shay, D. K., Waterman, S. H., \& Monto, A. S. (2010). Mask use, hand hygiene, and seasonal influenza-like illness among young adults: A randomized intervention trial. The Journal of Infectious Diseases, 201(4), 491-498. https://doi.org/10.1086/650396

Anderson, R. M., Heesterbeek, H., Klinkenberg, D., \& Hollingsworth, T. D. (2020). How will countrybased mitigation measures influence the course of the COVID-19 epidemic? The Lancet, 395(10228), 931-934. https://doi.org/10.1016/S0140-6736(20)30567-5

Aunger, R., Schmidt, W.-P., Ranpura, A., Coombes, Y., Maina, P. M., Matiko, C. N., \& Curtis, V. (2010). Three kinds of psychological determinants for hand-washing behaviour in Kenya. Social Science \& Medicine, 70(3), 383-391. https://doi.org/10.1016/j.socscimed.2009.10.038

Bavel, J. J. V., Baicker, K., Boggio, P. S., Capraro, V., Cichocka, A., Cikara, M., Crockett, M. J., Crum, A. J., Douglas, K. M., Druckman, J. N., Drury, J., Dube, O., Ellemers, N., Finkel, E. J., Fowler, J. H., Gelfand, M., Han, S., Haslam, S. A., Jetten, J., ... Willer, R. (2020). Using social and behavioural science to support COVID-19 pandemic response. Nature Human Behaviour, 1-12. https://doi.org/10.1038/s41562-020-0884-z

Belingheri, M., Paladino, M. E., \& Riva, M. A. (2020). COVID-19: Health prevention and control in nonhealthcare settings. Occupational Medicine, 70(2), 82-83. https://doi.org/10.1093/occmed/kqaa048

Bertsch, R. A. (2010). Avoiding Upper Respiratory Tract Infections by Not Touching the Face. Archives of Internal Medicine, 170(9), 833-834. https://doi.org/10.1001/archinternmed.2010.96

Best, M., \& Neuhauser, D. (2004). Ignaz Semmelweis and the birth of infection control. BMJ Quality \& Safety, 13(3), 233-234. https://doi.org/10.1136/qshc.2004.010918

Bialvaei, A. Z., Kafil, H. S., \& Asgharzadeh, M. (2015). Role of Treatment Cost on Transmission of Multidrug-Resistant Tuberculosis Into Iran. Clinical Infectious Diseases: An Official Publication of the Infectious Diseases Society of America, 61(6), 1029-1030. https://doi.org/10.1093/cid/civ459

Blendon, R. J., Koonin, L. M., Benson, J. M., Cetron, M. S., Pollard, W. E., Mitchell, E. W., Weldon, K. J., \& Herrmann, M. J. (2008). Public Response to Community Mitigation Measures for Pandemic 
Influenza. Emerging Infectious Diseases, 14(5), 778-786.

https://doi.org/10.3201/eid1405.071437

Borchgrevink, C. P., Cha, J., \& Kim, S. (2013). Hand Washing Practices in a College Town Environment. Journal of Environmental Health, 75(8), 18-25. JSTOR.

Bovet, A., \& Makse, H. A. (2019). Influence of fake news in Twitter during the 2016 US presidential election. Nature Communications, 10(1), 7. https://doi.org/10.1038/s41467-018-07761-2

Boyce, J. M., \& Pittet, D. (2002). Guideline for Hand Hygiene in Health-Care Settings: Recommendations of the Healthcare Infection Control Practices Advisory Committee and the HICPAC/SHEA/APIC/IDSA Hand Hygiene Task Force. Infection Control \& Hospital Epidemiology, 23(S12), S3-S40. https://doi.org/10.1086/503164

Braunack-Mayer, A. J., Tooher, R., \& Collins, J. (2013). Understanding the school community's response to school closures during the H1N1 2009 influenza. 18.

Brewer, N. T., Weinstein, N. D., Cuite, C. L., \& Herrington, J. E. (2004). Risk perceptions and their relation to risk behavior. Annals of Behavioral Medicine, 27(2), 125-130. https://doi.org/10.1207/s15324796abm2702_7

Briscese, G., Lacetera, N., Macis, M., \& Tonin, M. (2020). Compliance with COVID-19 SocialDistancing Measures in Italy: The Role of Expectations and Duration (Working Paper No. 26916; Working Paper Series). National Bureau of Economic Research. https://doi.org/10.3386/w26916

Brooks, S. K., Webster, R. K., Smith, L. E., Woodland, L., Wessely, S., Greenberg, N., \& Rubin, G. J. (2020). The psychological impact of quarantine and how to reduce it: Rapid review of the evidence. The Lancet, 395(10227), 912-920. https://doi.org/10.1016/S0140-6736(20)30460-8

Brzezinski, A., Kecht, V., Van Dijcke, D., \& Wright, A. L. (2020). Belief in Science Influences Physical Distancing in Response to COVID-19 Lockdown Policies (SSRN Scholarly Paper ID 3587990). Social Science Research Network. https://doi.org/10.2139/ssrn.3587990

Cava, M. A., Fay, K. E., Beanlands, H. J., McCay, E. A., \& Wignall, R. (2005). Risk Perception and Compliance With Quarantine During the SARS Outbreak. Journal of Nursing Scholarship, 37(4), 343-347. https://doi.org/10.1111/j.1547-5069.2005.00059.x

CDC. (2020, February 11). Coronavirus Disease 2019 (COVID-19). Centers for Disease Control and Prevention. https://www.cdc.gov/coronavirus/2019-ncov/hcp/hand-hygiene.html

Chan, J. F.-W., Yuan, S., Kok, K.-H., To, K. K.-W., Chu, H., Yang, J., Xing, F., Liu, J., Yip, C. C.-Y., Poon, R. W.-S., Tsoi, H.-W., Lo, S. K.-F., Chan, K.-H., Poon, V. K.-M., Chan, W.-M., Ip, J. D., Cai, J.-P., Cheng, V. C.-C., Chen, H., ... Yuen, K.-Y. (2020). A familial cluster of pneumonia associated with the 2019 novel coronavirus indicating person-to-person transmission: A study of a family cluster. The Lancet, 395(10223), 514-523. https://doi.org/10.1016/S01406736(20)30154-9

Chu, D. K., Akl, E. A., Duda, S., Solo, K., Yaacoub, S., Schünemann, H. J., Chu, D. K., Akl, E. A., Elharakeh, A., Bognanni, A., Lotfi, T., Loeb, M., Hajizadeh, A., Bak, A., Izcovich, A., CuelloGarcia, C. A., Chen, C., Harris, D. J., Borowiack, E., ... Schünemann, H. J. (2020). Physical distancing, face masks, and eye protection to prevent person-to-person transmission of SARSCoV-2 and COVID-19: A systematic review and meta-analysis. The Lancet, 395(10242), 19731987. https://doi.org/10.1016/S0140-6736(20)31142-9

Cirrincione, L., Plescia, F., Ledda, C., Rapisarda, V., Martorana, D., Moldovan, R. E., Theodoridou, K., \& Cannizzaro, E. (2020). COVID-19 Pandemic: Prevention and Protection Measures to Be Adopted at the Workplace. Sustainability, 12(9), 3603. https://doi.org/10.3390/su12093603

Cure, L., \& Van Enk, R. (2015). Effect of hand sanitizer location on hand hygiene compliance. American Journal of Infection Control, 43(9), 917-921. https://doi.org/10.1016/j.ajic.2015.05.013

Curtis, V. A., Danquah, L. O., \& Aunger, R. V. (2009). Planned, motivated and habitual hygiene behaviour: An eleven country review. Health Education Research, 24(4), 655-673. https://doi.org/10.1093/her/cyp002 
Dalton, C. B., Corbett, S. J., \& Katelaris, A. L. (2020). COVID-19: Implementing sustainable low cost physical distancing and enhanced hygiene. Medical Journal of Australia, 212(10), 443-446.e1. https://doi.org/10.5694/mja2.50602

Day, T., Park, A., Madras, N., Gumel, A., \& Wu, J. (2006). When Is Quarantine a Useful Control Strategy for Emerging Infectious Diseases? American Journal of Epidemiology, 163(5), 479-485. https://doi.org/10.1093/aje/kwj056

Dexter, F., Parra, M. C., Brown, J. R., \& Loftus, R. W. (2020). Perioperative COVID-19 Defense: An Evidence-Based Approach for Optimization of Infection Control and Operating Room Management. Anesthesia and Analgesia. https://doi.org/10.1213/ANE.0000000000004829

Dowell, S. F., Simmerman, J. M., Erdman, D. D., Wu, J.-S. J., Chaovavanich, A., Javadi, M., Yang, J.-Y., Anderson, L. J., Tong, S., \& Ho, M. S. (2004). Severe Acute Respiratory Syndrome Coronavirus on Hospital Surfaces. Clinical Infectious Diseases, 39(5), 652-657. https://doi.org/10.1086/422652

Drake, T. M., Docherty, A. B., Weiser, T. G., Yule, S., Sheikh, A., \& Harrison, E. M. (2020). The effects of physical distancing on population mobility during the COVID-19 pandemic in the UK. The Lancet Digital Health, 2(8), e385-e387. https://doi.org/10.1016/S2589-7500(20)30134-5

Eastwood, K., Durrheim, D., Francis, J. L., d'Espaignet, E. T., Duncan, S., Islama, F., \& Spearec, R. (2009). Knowledge about pandemic influenza and compliance with containment measures among Australians. Bulletin of the World Health Organization, 87(8), 588-594.

Edwards, R., Charani, E., Sevdalis, N., Alexandrou, B., Sibley, E., Mullett, D., Loveday, H. P., Drumright, L. N., \& Holmes, A. (2012). Optimisation of infection prevention and control in acute health care by use of behaviour change: A systematic review. The Lancet Infectious Diseases, 12(4), 318-329. https://doi.org/10.1016/S1473-3099(11)70283-3

Elder, N. C., Sawyer, W., Pallerla, H., Khaja, S., \& Blacker, M. (2014). Hand Hygiene and Face Touching in Family Medicine Offices: A Cincinnati Area Research and Improvement Group (CARInG) Network Study. The Journal of the American Board of Family Medicine, 27(3), 339346. https://doi.org/10.3122/jabfm.2014.03.130242

Esquivel-Gómez, J. de J., \& Barajas-Ramírez, J. G. (2018). Efficiency of quarantine and self-protection processes in epidemic spreading control on scale-free networks. Chaos (Woodbury, N.Y.), 28(1), 013119. https://doi.org/10.1063/1.5001176

Fathizadeh, H., Maroufi, P., Momen-Heravi, M., Dao, S., Köse, Ş., Ganbarov, K., Pagliano, P., Esposito, S., \& Kafil, H. S. (2020). Protection and disinfection policies against SARS-CoV-2 (COVID-19). Le Infezioni in Medicina, 28(2), 185-191.

Feng, S., Shen, C., Xia, N., Song, W., Fan, M., \& Cowling, B. J. (2020). Rational use of face masks in the COVID-19 pandemic. The Lancet Respiratory Medicine, 8(5), 434-436. https://doi.org/10.1016/S2213-2600(20)30134-X

Frenkel, S., Alba, D., \& Zhong, R. (2020, March 8). Surge of Virus Misinformation Stumps Facebook and Twitter. The New York Times. https:/www.nytimes.com/2020/03/08/technology/coronavirusmisinformation-social-media.html

Furuya, H. (2007). Risk of transmission of airborne infection during train commute based on mathematical model. Environmental Health and Preventive Medicine, 12(2), 78-83. https://doi.org/10.1007/BF02898153

Goldmann, D. A. (2000). Transmission of viral respiratory infections in the home. The Pediatric Infectious Disease Journal, 19(10), S97.

Gould, D., Moralejo, D., Drey, N., Chudleigh, J., \& Taljaard, M. (2018). Interventions to improve hand hygiene compliance in patient care: Reflections on three systematic reviews for the Cochrane Collaboration 2007-2017. Journal of Infection Prevention, 19(3), 108-113. https://doi.org/10.1177/1757177417751285

Hobbs, M. A., Robinson, S., Neyens, D. M., \& Steed, C. (2016). Visitor characteristics and alcohol-based hand sanitizer dispenser locations at the hospital entrance: Effect on visitor use rates. American Journal of Infection Control, 44(3), 258-262. https://doi.org/10.1016/j.ajic.2015.10.041 
Hogg, W., \& Huston, P. (2006). Controlling droplet-transmitted respiratory infections. Canadian Family Physician, 52(10), 1229-1232.

Holmes, B. J. (2008). Communicating about emerging infectious disease: The importance of research. Health, Risk \& Society, 10(4), 349-360. https://doi.org/10.1080/13698570802166431

Huremović, D. (2019). Social Distancing, Quarantine, and Isolation. In D. Huremović (Ed.), Psychiatry of Pandemics: A Mental Health Response to Infection Outbreak (pp. 85-94). Springer International Publishing. https://doi.org/10.1007/978-3-030-15346-5_8

Islam, N., Sharp, S. J., Chowell, G., Shabnam, S., Kawachi, I., Lacey, B., Massaro, J. M., D’Agostino, R. B., \& White, M. (2020). Physical distancing interventions and incidence of coronavirus disease 2019: Natural experiment in 149 countries. $B M J, 370$. https://doi.org/10.1136/bmj.m2743

Jarvis, C. I., Van Zandvoort, K., Gimma, A., Prem, K., CMMID COVID-19 working group, Klepac, P., Rubin, G. J., \& Edmunds, W. J. (2020). Quantifying the impact of physical distance measures on the transmission of COVID-19 in the UK. BMC Medicine, 18(1), 124. https://doi.org/10.1186/s12916-020-01597-8

Jarvis, W. (1994). Handwashing - The Semmelweis lesson forgotten? The Lancet, 344(8933), 13111312. https://doi.org/10.1016/S0140-6736(94)90687-4

Jefferson, T., Mar, C. D., Dooley, L., Ferroni, E., Al-Ansary, L. A., Bawazeer, G. A., Driel, M. L. van, Foxlee, R., \& Rivetti, A. (2009). Physical interventions to interrupt or reduce the spread of respiratory viruses: Systematic review. BMJ, 339. https://doi.org/10.1136/bmj.b3675

Kampf, G., Todt, D., Pfaender, S., \& Steinmann, E. (2020). Persistence of coronaviruses on inanimate surfaces and their inactivation with biocidal agents. Journal of Hospital Infection, 104(3), 246251. https://doi.org/10.1016/j.jhin.2020.01.022

Kass-Hout, T. A., \& Alhinnawi, H. (2013). Social media in public health. British Medical Bulletin, 108, 5-24. https://doi.org/10.1093/bmb/ldt028

Ki, H. K., Han, S. K., Son, J. S., \& Park, S. O. (2019). Risk of transmission via medical employees and importance of routine infection-prevention policy in a nosocomial outbreak of Middle East respiratory syndrome (MERS): A descriptive analysis from a tertiary care hospital in South Korea. BMC Pulmonary Medicine, 19(1), 190. https://doi.org/10.1186/s12890-019-0940-5

Killingley, B., Enstone, J., Booy, R., Hayward, A., Oxford, J., Ferguson, N., \& Van-Tam, J. N. (2011). Potential role of human challenge studies for investigation of influenza transmission. The Lancet Infectious Diseases, 11(11), 879-886. https://doi.org/10.1016/S1473-3099(11)70142-6

Kim, E. A. (2020). Social Distancing and Public Health Guidelines at Workplaces in Korea: Responses to COVID-19. Safety and Health at Work. https://doi.org/10.1016/j.shaw.2020.07.006

Koh, D. (2020). Occupational risks for COVID-19 infection. Occupational Medicine (Oxford, England), 70(1), 3-5. https://doi.org/10.1093/occmed/kqaa036

Kratzel, A., Todt, D., V'kovski, P., Steiner, S., Gultom, M., Thao, T. T. N., Ebert, N., Holwerda, M., Steinmann, J., Niemeyer, D., Dijkman, R., Kampf, G., Drosten, C., Steinmann, E., Thiel, V., \& Pfaender, S. (2020). Inactivation of Severe Acute Respiratory Syndrome Coronavirus 2 by WHORecommended Hand Rub Formulations and Alcohols. Emerging Infectious Diseases, 26(7). https://doi.org/10.3201/eid2607.200915

Kretzer, E. K., \& Larson, E. L. (1998). Behavioral interventions to improve infection control practices. American Journal of Infection Control, 26(3), 245-253. https://doi.org/10.1016/S01966553(98)80008-4

Kwok, Y. L. A., Gralton, J., \& McLaws, M.-L. (2015). Face touching: A frequent habit that has implications for hand hygiene. American Journal of Infection Control, 43(2), 112-114. https://doi.org/10.1016/j.ajic.2014.10.015

Lake, M. A. (2020). What we know so far: COVID-19 current clinical knowledge and research. Clinical Medicine, 20(2), 124-127. https://doi.org/10.7861/clinmed.2019-coron

Larson, E., \& Kretzer, E. K. (1995). Compliance with handwashing and barrier precautions. Journal of Hospital Infection, 30, 88-106. https://doi.org/10.1016/0195-6701(95)90010-1 
Larson, Elaine. (1988). A Causal Link Between Handwashing and Risk of Infection? Examination of the Evidence. Infection Control \& Hospital Epidemiology, 9(1), 28-36. https://doi.org/10.1086/645729

Lerner, J. S., \& Keltner, D. (2001). Fear, anger, and risk. Journal of Personality and Social Psychology, 81(1), 146-159. https://doi.org/10.1037/0022-3514.81.1.146

Lewnard, J. A., \& Lo, N. C. (2020). Scientific and ethical basis for social-distancing interventions against COVID-19. The Lancet. Infectious Diseases, 20(6), 631-633. https://doi.org/10.1016/S14733099(20)30190-0

Luby, S. P., Agboatwalla, M., Feikin, D. R., Painter, J., Billhimer, W., Altaf, A., \& Hoekstra, R. M. (2005). Effect of handwashing on child health: A randomised controlled trial. The Lancet, 366(9481), 225-233. https://doi.org/10.1016/S0140-6736(05)66912-7

Lunn, P. D., Belton, C. A., Lavin, C., McGowan, F. P., Timmons, S., \& Robertson, D. A. (2020). Using Behavioral Science to help fight the Coronavirus. Journal of Behavioral Public Administration, 3(1), Article 1. https://doi.org/10.30636/jbpa.31.147

Luttrell, A., Petty, R. E., Briñol, P., \& Wagner, B. C. (2016). Making it moral: Merely labeling an attitude as moral increases its strength. Journal of Experimental Social Psychology, 65, 82-93. https://doi.org/10.1016/j.jesp.2016.04.003

Maunder, R. (2004). The experience of the 2003 SARS outbreak as a traumatic stress among frontline healthcare workers in Toronto: Lessons learned. Philosophical Transactions of the Royal Society B: Biological Sciences, 359(1447), 1117. https://doi.org/10.1098/rstb.2004.1483

Mbakaya, B. C., Lee, P. H., \& Lee, R. L. T. (2017). Hand Hygiene Intervention Strategies to Reduce Diarrhoea and Respiratory Infections among Schoolchildren in Developing Countries: A Systematic Review. International Journal of Environmental Research and Public Health, 14(4), 371. https://doi.org/10.3390/ijerph14040371

Michie, S., Richardson, M., Johnston, M., Abraham, C., Francis, J., Hardeman, W., Eccles, M. P., Cane, J., \& Wood, C. E. (2013). The behavior change technique taxonomy (v1) of 93 hierarchically clustered techniques: Building an international consensus for the reporting of behavior change interventions. Annals of Behavioral Medicine: A Publication of the Society of Behavioral Medicine, 46(1), 81-95. https://doi.org/10.1007/s12160-013-9486-6

Michie, S., van Stralen, M., \& West, R. (2011). The Behaviour Change Wheel: A new method for characterising and designing behaviour change interventions. Implementation Science : IS, 6, 42. https://doi.org/10.1186/1748-5908-6-42

Naikoba, S., \& Hayward, A. (2001). The effectiveness of interventions aimed at increasing handwashing in healthcare workers-A systematic review. Journal of Hospital Infection, 47(3), 173-180. https://doi.org/10.1053/jhin.2000.0882

Nicas, M., \& Best, D. (2008). A Study Quantifying the Hand-to-Face Contact Rate and Its Potential Application to Predicting Respiratory Tract Infection. Journal of Occupational and Environmental Hygiene, 5(6), 347-352. https://doi.org/10.1080/15459620802003896

O’Boyle, C. A., Henly, S. J., \& Larson, E. (2001). Understanding adherence to hand hygiene recommendations: The theory of planned behavior. American Journal of Infection Control, 29(6), 352-360. https://doi.org/10.1067/mic.2001.18405

Oh, S.-H., Lee, S. Y., \& Han, C. (2020). The Effects of Social Media Use on Preventive Behaviors during Infectious Disease Outbreaks: The Mediating Role of Self-relevant Emotions and Public Risk Perception. Health Communication, O(0), 1-10. https://doi.org/10.1080/10410236.2020.1724639

Otter, J. A., Donskey, C., Yezli, S., Douthwaite, S., Goldenberg, S. D., \& Weber, D. J. (2016). Transmission of SARS and MERS coronaviruses and influenza virus in healthcare settings: The possible role of dry surface contamination. Journal of Hospital Infection, 92(3), 235-250. https://doi.org/10.1016/j.jhin.2015.08.027

Pittet, D. (2000). Improving Compliance With Hand Hygiene in Hospitals. Infection Control \& Hospital Epidemiology, 21(6), 381-386. https://doi.org/10.1086/501777 
Pittet, D., Hugonnet, S., Harbarth, S., Mourouga, P., Sauvan, V., Touveneau, S., \& Perneger, T. V. (2000). Effectiveness of a hospital-wide programme to improve compliance with hand hygiene. The Lancet, 356(9238), 1307-1312. https://doi.org/10.1016/S0140-6736(00)02814-2

Prem, K., Liu, Y., Russell, T. W., Kucharski, A. J., Eggo, R. M., Davies, N., Flasche, S., Clifford, S., Pearson, C. A. B., Munday, J. D., Abbott, S., Gibbs, H., Rosello, A., Quilty, B. J., Jombart, T., Sun, F., Diamond, C., Gimma, A., van Zandvoort, K., ... Klepac, P. (2020). The effect of control strategies to reduce social mixing on outcomes of the COVID-19 epidemic in Wuhan, China: A modelling study. The Lancet Public Health, 5(5), e261-e270. https://doi.org/10.1016/S24682667(20)30073-6

Rasmussen, S. A., Jamieson, D. J., \& Bresee, J. S. (2008). Pandemic Influenza and Pregnant Women. Emerging Infectious Diseases, 14(1), 95-100. https://doi.org/10.3201/eid1401.070667

Rosenberger, L. H., Riccio, L. M., Campbell, K. T., Politano, A. D., \& Sawyer, R. G. (2012). Quarantine, Isolation, and Cohorting: From Cholera to Klebsiella. Surgical Infections, 13(2), 69-73. https://doi.org/10.1089/sur.2011.067

Rucker, D. D., Tormala, Z. L., Petty, R. E., \& Briñol, P. (2014). Consumer conviction and commitment: An appraisal-based framework for attitude certainty. Journal of Consumer Psychology, 24(1), 119-136. https://doi.org/10.1016/j.jcps.2013.07.001

Ryan, M. A. K., Christian, R. S., \& Wohlrabe, J. (2001). Handwashing and respiratory illness among young adults in military training 1 The full text of this article is available via AJPM Online at www.elsevier.com/locate/ajpmonline. American Journal of Preventive Medicine, 21(2), 79-83. https://doi.org/10.1016/S0749-3797(01)00323-3

Sawyer, W. P., \& White, Z. (2015). Hand Awareness: A Solution Not a Revolution for Respiratory Infections. NASN School Nurse, 30(1), 15-19. https://doi.org/10.1177/1942602X14559421

Sheeran, P., Harris, P. R., \& Epton, T. (2014). Does heightening risk appraisals change people's intentions and behavior? A meta-analysis of experimental studies. Psychological Bulletin, 140(2), 511-543. https://doi.org/10.1037/a0033065

Siddharta, A., Pfaender, S., Vielle, N. J., Dijkman, R., Friesland, M., Becker, B., Yang, J., Engelmann, M., Todt, D., Windisch, M. P., Brill, F. H., Steinmann, J., Steinmann, J., Becker, S., Alves, M. P., Pietschmann, T., Eickmann, M., Thiel, V., \& Steinmann, E. (2017). Virucidal Activity of World Health Organization-Recommended Formulations Against Enveloped Viruses, Including Zika, Ebola, and Emerging Coronaviruses. The Journal of Infectious Diseases, 215(6), 902-906. https://doi.org/10.1093/infdis/jix046

Sim, S. W., Moey, K. S. P., \& Tan, N. C. (2014). The use of facemasks to prevent respiratory infection: A literature review in the context of the Health Belief Model. Singapore Medical Journal, 55(3), 160-167. https://doi.org/10.11622/smedj.2014037

Teare, E. L., Cookson, B., French, G. L., Jenner, E. A., Scott, G., Pallett, A., Gould, D., Schweiger, M., Wilson, J., \& Stone, S. (1999). UK handwashing initiative. Journal of Hospital Infection, 43(1), 1-3. https://doi.org/10.1053/jhin.1999.0251

The Behavioural Insights Team. Retrieved July 18, 2020, from https://www.bi.team/

Toppenberg-Pejcic, D., Noyes, J., Allen, T., Alexander, N., Vanderford, M., \& Gamhewage, G. (2019). Emergency Risk Communication: Lessons Learned from a Rapid Review of Recent Gray Literature on Ebola, Zika, and Yellow Fever. Health Communication, 34(4), 437-455. https://doi.org/10.1080/10410236.2017.1405488

Tuite, A. R., Fisman, D. N., \& Greer, A. L. (2020). Mathematical modelling of COVID-19 transmission and mitigation strategies in the population of Ontario, Canada. CMAJ: Canadian Medical Association Journal = Journal de l'Association Medicale Canadienne, 192(19), E497-E505. https://doi.org/10.1503/cmaj.200476

Vaughan, E., \& Tinker, T. (2009). Effective health risk communication about pandemic influenza for vulnerable populations. American Journal of Public Health, 99(S2), 324-332. 
Voss, A., \& Widmer, A. F. (1997). No Time for Handwashing!? Handwashing Versus Alcoholic Rub Can We Afford 100\% Compliance? Infection Control \& Hospital Epidemiology, 18(3), 205-208. https://doi.org/10.2307/30141985

Webb, A. (2015). Quarantine, Isolation, and Health Care Workers. CONTINUUM: Lifelong Learning in Neurology, 21(6), 1745. https://doi.org/10.1212/CON.0000000000000253

Webster, R. K., Brooks, S. K., Smith, L. E., Woodland, L., Wessely, S., \& Rubin, G. J. (2020). How to improve adherence with quarantine: Rapid review of the evidence. Public Health, 182, 163-169. https://doi.org/10.1016/j.puhe.2020.03.007

West, R., Michie, S., Rubin, G. J., \& Amlôt, R. (2020). Applying principles of behaviour change to reduce SARS-CoV-2 transmission. Nature Human Behaviour, 4(5), 451-459. https://doi.org/10.1038/s41562-020-0887-9

White, C., Kolble, R., Carlson, R., Lipson, N., Dolan, M., Ali, Y., \& Cline, M. (2003). The effect of hand hygiene on illness rate among students in university residence halls. American Journal of Infection Control, 31(6), 364-370. https://doi.org/10.1016/S0196-6553(03)00041-5

Whitworth, J. (2020). COVID-19: A fast evolving pandemic. Transactions of The Royal Society of Tropical Medicine and Hygiene, 114(4), 241-248. https://doi.org/10.1093/trstmh/traa025

Wiboonchutikul, S., Manosuthi, W., Likanonsakul, S., Sangsajja, C., Kongsanan, P., Nitiyanontakij, R., Thientong, V., Lerdsamran, H., \& Puthavathana, P. (2016). Lack of transmission among healthcare workers in contact with a case of Middle East respiratory syndrome coronavirus infection in Thailand. Antimicrobial Resistance \& Infection Control, 5(1), 21. https://doi.org/10.1186/s13756-016-0120-9

Wilder-Smith, A., Chiew, C. J., \& Lee, V. J. (2020). Can we contain the COVID-19 outbreak with the same measures as for SARS? The Lancet Infectious Diseases, 20(5), e102-e107. https://doi.org/10.1016/S1473-3099(20)30129-8 